\title{
EVALUATION OF ROOF SLOPE AND EXPOSURE WITH DIFFERENT ROOFING MATERIALS IN REDUCED MODELS OF ANIMAL PRODUCTION FACILITIES IN SPRING AND SUMMER
}

\author{
THIAGO V. MELO ${ }^{1}$, RENATO L. FURLAN ${ }^{2}$, ADHEMAR P. MILANI ${ }^{3}$, MARCOS E. \\ BUZANSKAS $^{4}$, DIEGO A. MOTA ${ }^{5}$
}

\begin{abstract}
The present study was conducted at the Department of Rural Engineering and the Department of Animal Morphology and Physiology of FCAV/Unesp, Jaboticabal, SP, Brazil. The objective was to verify the influence of roof slope, exposure and roofing material on the internal temperature of reduced models of animal production facilities. For the development of the research, 48 reduced and dissemble models with dimensions $1.00 \times 1.00 \times 0.50 \mathrm{~m}$ were used. The roof was shed-type, and the models faced to the North or South directions, with 24 models for each side of exposure. Ceramic, galvanized-steel and fibro tiles were used to build the roofs. Slopes varied between 20, 30, 40 and 50\% for the ceramic tile and 10, 30, 40 and 50\% for the other two. Inside the models, temperature readings were performed at every hour, for 12 months. The results were evaluated in a general linear model in a nested $3 \times 4 \times 2$ factorial arrangement, in which the effects of roofing material and exposure were nested on the factor Slope. Means were compared by the Tukey test at $5 \%$ of probability. After analyzing the data, we observed that with the increase in the slope and exposure to the South, there was a drop in the internal temperature within the model at the geographic coordinates of Jaboticabal city (SP/Brazil).
\end{abstract}

KEYWORDS: ambience, heat, shed.

\section{AVALIAÇÃO DA INCLINAÇÃO E EXPOSIÇÃO DE TELHADO EM DIFERENTES MATERIAIS DE COBERTURA EM MODELOS REDUZIDOS DE INSTALAÇÕES ZOOTÉCNICAS NA PRIMAVERA E VERÃO}

RESUMO: O presente trabalho foi desenvolvido junto aos Departamentos de Engenharia Rural e Morfologia e Fisiologia Animal da FCAV/Unesp, Jaboticabal - SP. Objetivou-se verificar a influência da inclinação , exposição e cobertura sobre a temperatura interna de modelos reduzidos de instalações zootécnicas. Para o desenvolvimento da pesquisa, foram utilizados 48 modelos reduzidos e dissimilares nas dimensões de $1,00 \times 1,00 \times 0,50$ metros. A cobertura foi de uma água, dispostos nas exposições norte-sul, sendo 24 modelos na exposição norte e 24 na sul. Foram utilizadas, na cobertura, telha de cerâmica, aço galvanizado e fibrocimento. As inclinações variaram de 20; 30; 40 e 50\% para telha de cerâmica e 10; 30; 40 e 50\% para as demais. No interior dos modelos, foram realizadas leituras de temperatura, de hora em hora, durante 12 meses. Os resultados obtidos foram avaliados num modelo linear geral, no esquema fatorial aninhado $3 \times 4 \times$ 2, em que foram considerados: tipo de telha, grau de inclinação e exposição, onde os efeitos de cobertura e exposição foram aninhados no fator inclinação. As médias obtidas foram comparadas pelo teste de Tukey, a 5\% de probabilidade. Após a análise dos dados, observa-se que, com o aumento da inclinação na exposição sul, houve decréscimo da temperatura interna no interior do modelo, nas coordenadas geográficas da cidade de Jaboticabal.

PALAVRAS-CHAVE: ambiência, calor, galpão.

\footnotetext{
${ }^{1}$ Zootecnista. Prof. Doutor em Zootecnia, Instituto de Ciências Agrárias da Universidade Federal dos Vales Jequitinhonha e Mucuri, Campus Unaí/ Mg. (38) 97325255, thiago.melo@ufvjm.edu.br

${ }^{2}$ Zootecnista. Prof. Doutor em Zootecnia, Departamento de Morfologia e Fisiologia Animal, Universidade Estadual Paulista "Júlio de Mesquita Filho" Campus de Jaboticabal/SP, rlfurlan@fcav.unesp.br

${ }^{3}$ Engenheiro Civil. Prof. Doutor em Engenharia Civil, Departamento de Engenharia Rural, Universidade Estadual Paulista "Júlio de Mesquita Filho" Campus de Jaboticabal/SP, apmilani@fcav.unesp.br

${ }^{4}$ Zootecnista. Doutor em Melhoramento Genético, Departamento de Ciências Exatas, Universidade Estadual Paulista "Júlio de Mesquita Filho" Campus de Jaboticabal/SP, marcosbuz@yahoo.com.br

${ }^{5}$ Zootecnista. Prof. Doutor em Zootecnia. Universidade Federal da Fronteira Sul, Campus

Erechim/RS, diegomota@zootecnista.com.br
}

Recebido pelo Conselho Editorial em: 09-9-2013

Aprovado pelo Conselho Editorial em: 30-5-2014 


\section{INTRODUCTION}

The animal environment is constituted of the combined effect of several elements that interact with the animal itself. Thus, the animal production facility is aimed at providing comfort to increase production and productivity in the animal husbandry activity. The facilities also receive direct action from the climate, and so they must be built aiming mainly at reducing these influences and provide greater comfort to animals. The most economical means of keeping the animals within their comfort zone is to control the incoming radiation. According to SEVEGNANI et al. (1994), along with the great thermal charge, radiation from the sun and from the sky is simply and substantially reduced with roofs that minimize the incidence of solar energy, and this is where the solar radiation most intensely acts.

The development of research studies on animal production facilities in natural scale is too costly, not only because of their large dimensions, but also because it is impossible to have replications of statistical nature (RODRIGUES, 1998). Hence, the use of reduced models has been a good solution to solve the abovementioned problems. Therefore, models are a widely utilized tool in engineering, but their use requires clear understanding of the principles that determine the relation between the models.

The quantitative observation of the solar radiation that hits the inclined surfaces in relation to the horizontal surface, with different slope angles, is utilized in a large variety of applications, including engineering projects for solar panels, architecture projects, urban planning, agronomic studies of insolation on the vegetation and in micrometeorological studies on local circulation. The total amount of radiation hitting a surface varies according to the exposure and declivity (COAN, 2008). In this research, to corroborate with any of these studies, it is necessary to know the intensity of incident solar radiation on an inclined surface and its seasonal variation over a year (SCOLAR, 2003).

The objective of this study was to verify the influence of slope, in North and South exposures in ceramic tile, galvanized steel and fibro roofs on the internal temperature of reduced models of animal production facilities.

\section{MATERIAL AND METHODS}

The experiment was conducted at the Department of Rural Engineering and the Department of Animal Morphology and Physiology of the Faculdade de Ciências Agrárias e Veterinárias (FCAV/Unesp), located in Jaboticabal/SP, Brazil. Forty-eight dissemble reduced models with dimensions $1.00 \times 1.00 \times 0.50 \mathrm{~m}$ were built, having the same air volume inside of each one. According to MURPHY (1950), dissemble reduced models are those in which the original model have quite distinct physical qualities but have in common structural and functional characteristics. The use of analogy results in physically similar models. Wooden rods of different sizes were built to incline them. The models were built on the Campus of Unesp, Jaboticabal, located at $21^{\circ} 14^{\prime} 05^{\prime \prime}$ South latitude, 48 $17^{\prime} 09^{\prime \prime}$ West longitude and 615.01m altitude, utilizing an area of $160 \mathrm{~m}^{2}$.

The material utilized was plywood with $6.0 \mathrm{~mm}$ of thickness on the sides and on the bottom so as to avoid the effect of the climate variables from outdoors as much as possible, so that the alterations in the internal environment did not undergo major effects originated from the roof. The reduced models, made of plywood, were painted with waterproof white paint to increase their reflectivity and endurance against weathering. Roofs were shed-like, with models facing East-West, and their roofs facing North-South; half of the models faced the North, and the other 24 faced the South direction, with two replications per slope. The models were covered with $0.5 \mathrm{~mm}$ tick roman ceramic; $0.5 \mathrm{~mm}$ thick galvanized steel; and 6.00 thick fibro tiles. The slopes of the roofs varied between 20, 30, 40 and 50\% for the ceramic tile and 10, 30, 40 and 50\% for the others. The slope of $10 \%$ was not used in the ceramic roof because according to the technical engineering specifications, ceramic tiles cannot be set up with slopes lower than $20 \%$. 
We evaluated the ceramic, galvanized steel and fibro tiles and different roof slopes and their (North/South) exposure as to their influence on the internal temperature of the models. The data on the external environment of the experiment were collected by a conventional, automated meteorological station at the Department of Exact Sciences of UNESP/Jaboticabal. To obtain the data on the internal temperature of the models, one type- $T$ thermocouple model 105T with accuracy of $\pm 1^{\circ} \mathrm{C}$ was properly positioned at the center of the model and another at two centimeters below the roof, held by wood supports. The data on internal temperature of the models were read at every hour, for one year, using data acquisition system Datalogger (Campbell Scientific Inc). After collecting the data, they were filtered to exclude the days that had an insolation ratio above 85\% (obtained from the meteorological station of Department of Exact Sciences of UNESP/Jaboticabal) so as to avoid the cloudy and rainy days. For the statistical data analyses, the temperatures recorded at $12 \mathrm{~h} 00$ and $14 \mathrm{~h} 00$ were used, so as to maximize the effect of temperature on the model, separated between the summer and spring seasons. The estimated solar radiation data were collected at the Meteorological Station of the Department of Rural Engineering of FCAV/UNESP on a structure named "Experimental River Basin", described in detail by TURCO (1997), in which the filtered days with insolation ratio above $85 \%$ were used.

The results were evaluated in a general linear model by statistical package SAS 9.1 (SAS Institute, Cary, NC, USA) on a nested $3 \times 4 \times 2$ factorial arrangement for the roofing material, roof slope and North/South exposure values. The effects of roofing material and exposure were nested in the slope factor. The means were compared by the Tukey test at $5 \%$ of probability by following the statistical model below:

$$
Y i j k l=m+C i+E j+C E(i j)+I k:(C i E j)+e i j k l
$$

where,

Yijkl = observation of roof $\mathrm{i}$, with slope $\mathrm{j}$ and exposure $\mathrm{k}$;

$\mathrm{m}=$ overall mean;

$\mathrm{Ci}=$ effect of roofing material $\mathrm{i}$, where $\mathrm{i}=1,2,3$;

$\mathrm{Ej}=$ effect of exposure $\mathrm{j}$, where $\mathrm{j}=1,2$;

$\mathrm{CE}(\mathrm{ik})=$ effect of the interaction between roofing material $\mathrm{i}$ and exposure $\mathrm{j}$;

Ik : $(\mathrm{CiEj})=$ effects of the interaction slope $\mathrm{k}$ nested between roofing material $\mathrm{i}$ and exposure $\mathrm{j}$, and

$\mathrm{ijk}=$ error associated with each observation.

\section{RESULTS AND DISCUSSION}

According to the results shown in Table 1, we can observe that when the slope of the Southfacing roof was increased, global solar radiation reduced. This is due to the lower incidence of estimated global solar radiation on sloped surfaces facing the South, although this was not observed with greater clarity in the internal temperature of the prototypes (Figures 1, 2 and 3).

TABLE 1. Estimated global solar radiation for the slopes of 10, 20, 30, 40 and 50\% on the Northand South-facing roofs during the hottest day of the experimental period in Jaboticabal.

\begin{tabular}{lccccccccccc}
\hline \multicolumn{10}{c}{ Estimated radiation (cal/cm²/day) } \\
\hline & $10 \mathrm{~N}$ & $10 \mathrm{~S}$ & $20 \mathrm{~N}$ & $20 \mathrm{~S}$ & $30 \mathrm{~N}$ & $30 \mathrm{~S}$ & $40 \mathrm{~N}$ & $40 \mathrm{~S}$ & $50 \mathrm{~N}$ & $50 \mathrm{~S}$ \\
Summer & 634.5 & 630.7 & 627.2 & 619.7 & 614.8 & 603.5 & 598.1 & 583.2 & 578.3 & 560.2 \\
Spring & 449.9 & 454.9 & 440.9 & 450.8 & 428.5 & 442.8 & 413.2 & 431.5 & 396.2 & 418.0 \\
\hline
\end{tabular}



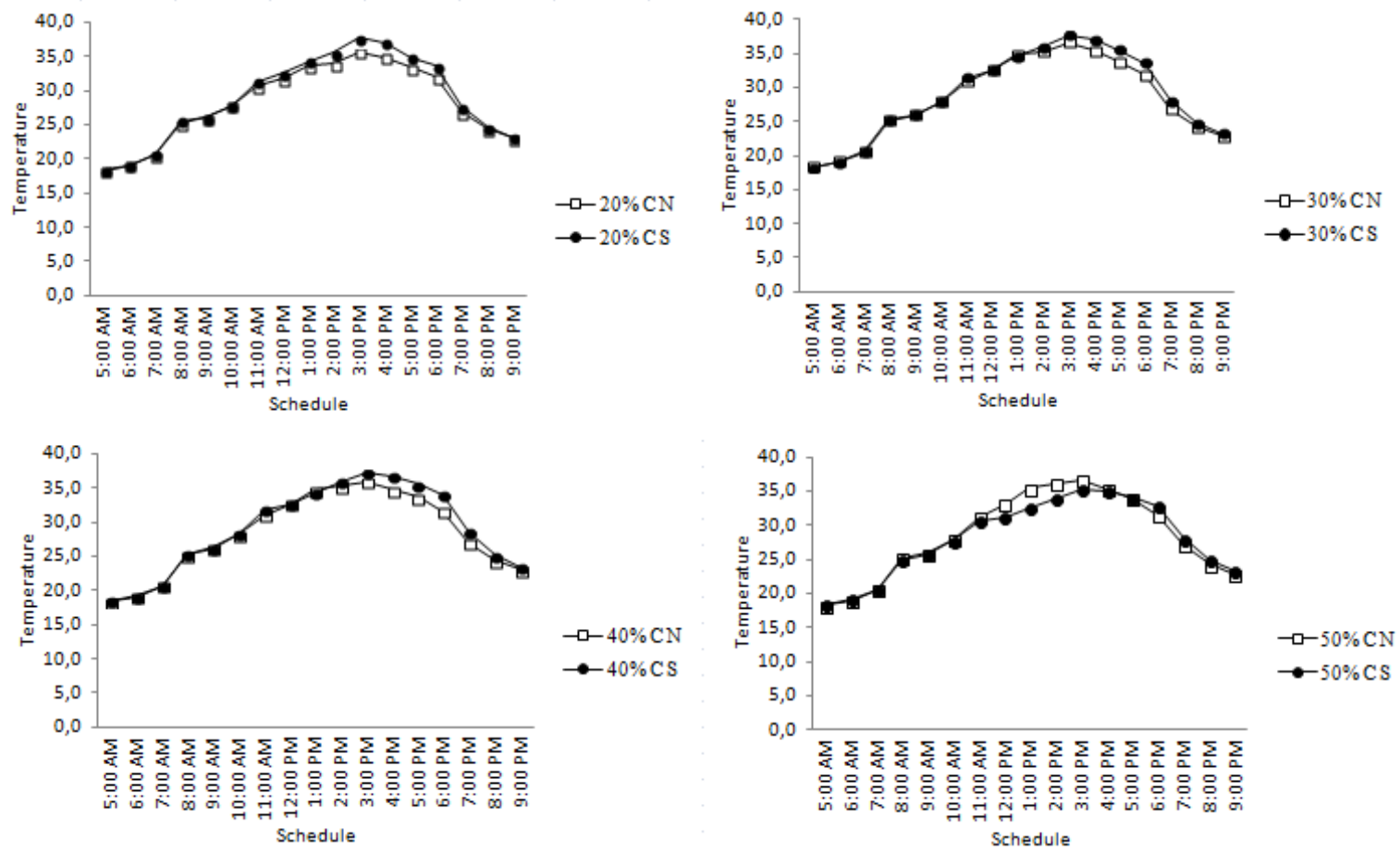

FIGURE 1. Temperature variation in the shed during the critical summer day with the North- and South-facing ceramic roofs, with slopes of 20\%, 30\% , $40 \%$ and 50\%.
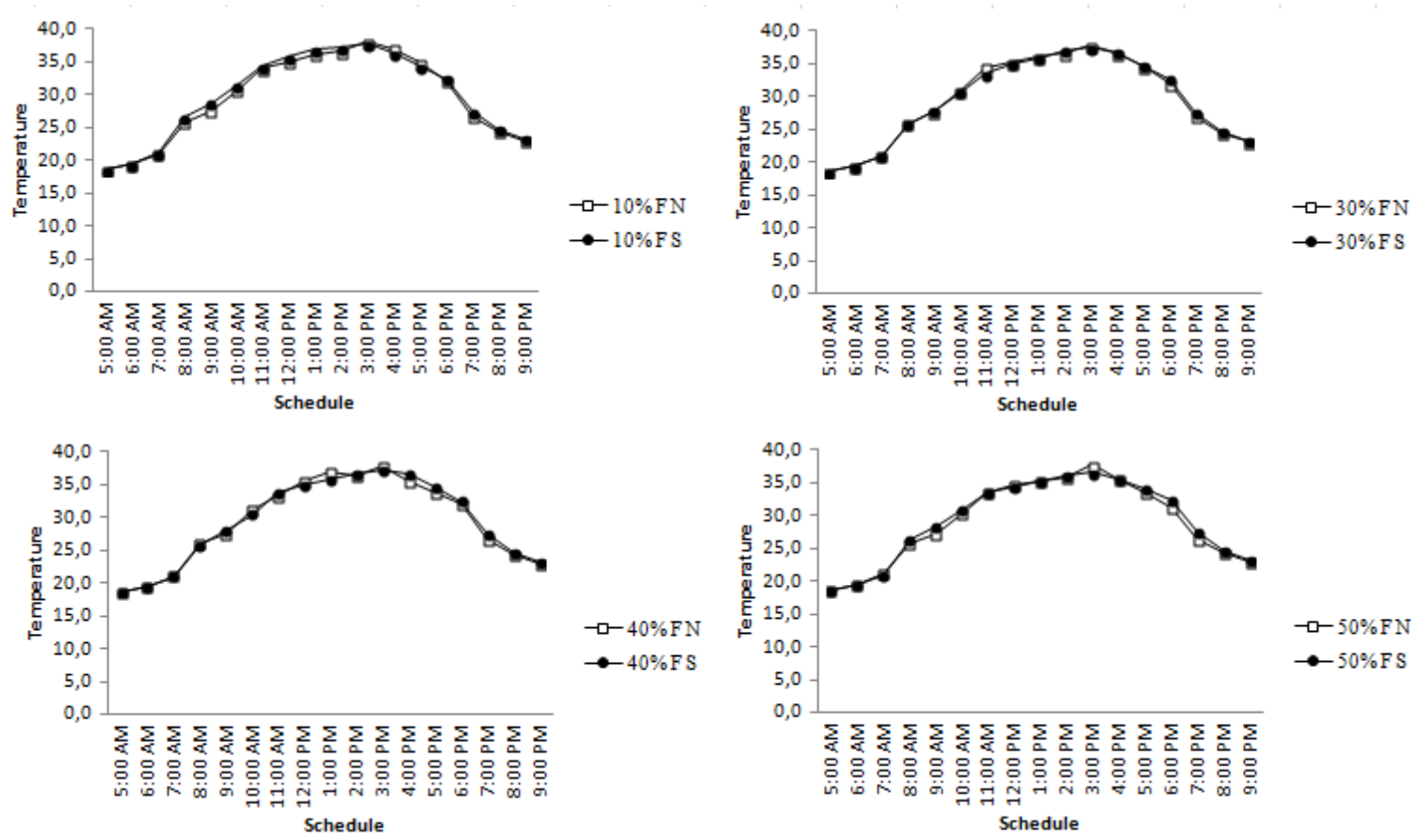

FIGURE 2. Temperature variation in the shed during the critical summer day with the North- and South-facing fibro roofs, with slopes of $10 \%, 30 \%, 40 \%$ and $50 \%$. 

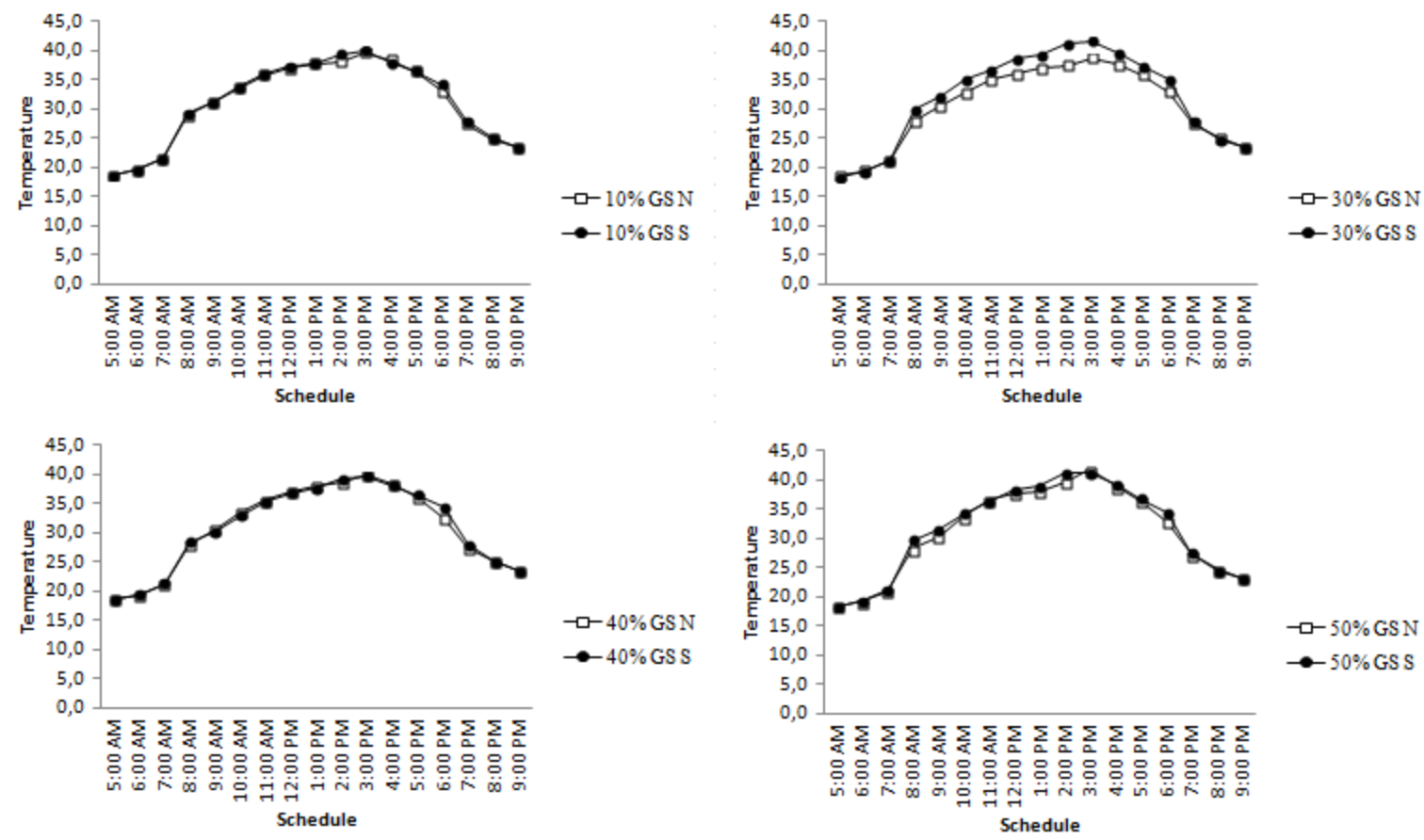

FIGURE 3. Temperature variation in the shed during the critical summer day with the North- and South-facing galvanized-steel roofs, with slopes of $10 \%, 30 \%, 40 \%$ and $50 \%$.

Analyzing the temperature variations between the roofing materials (Figure 4), we can observe the thermal characteristics of the roofs, in which the ceramic tile showed less accented temperature curves over the day, thereby demonstrating its better thermal inertia in relation to the fibro and galvanized steel roofs. Results that better confirm the performance of the ceramic tile in the literature are plenty (PARKER, 1963; SEVEGNANI et al., 1994; JÁCOME et al., 2007; FURTADO et al., 2003; SANTOS et al., 2005). This is due to the physical properties of the ceramic roof, especially its conductivity, thermal inertia, and specific mass and heat of the material that constitutes the ceramic tile, and according to RODRIGUES (1998), these characteristics are essential for the thermal efficiency of roofs. 

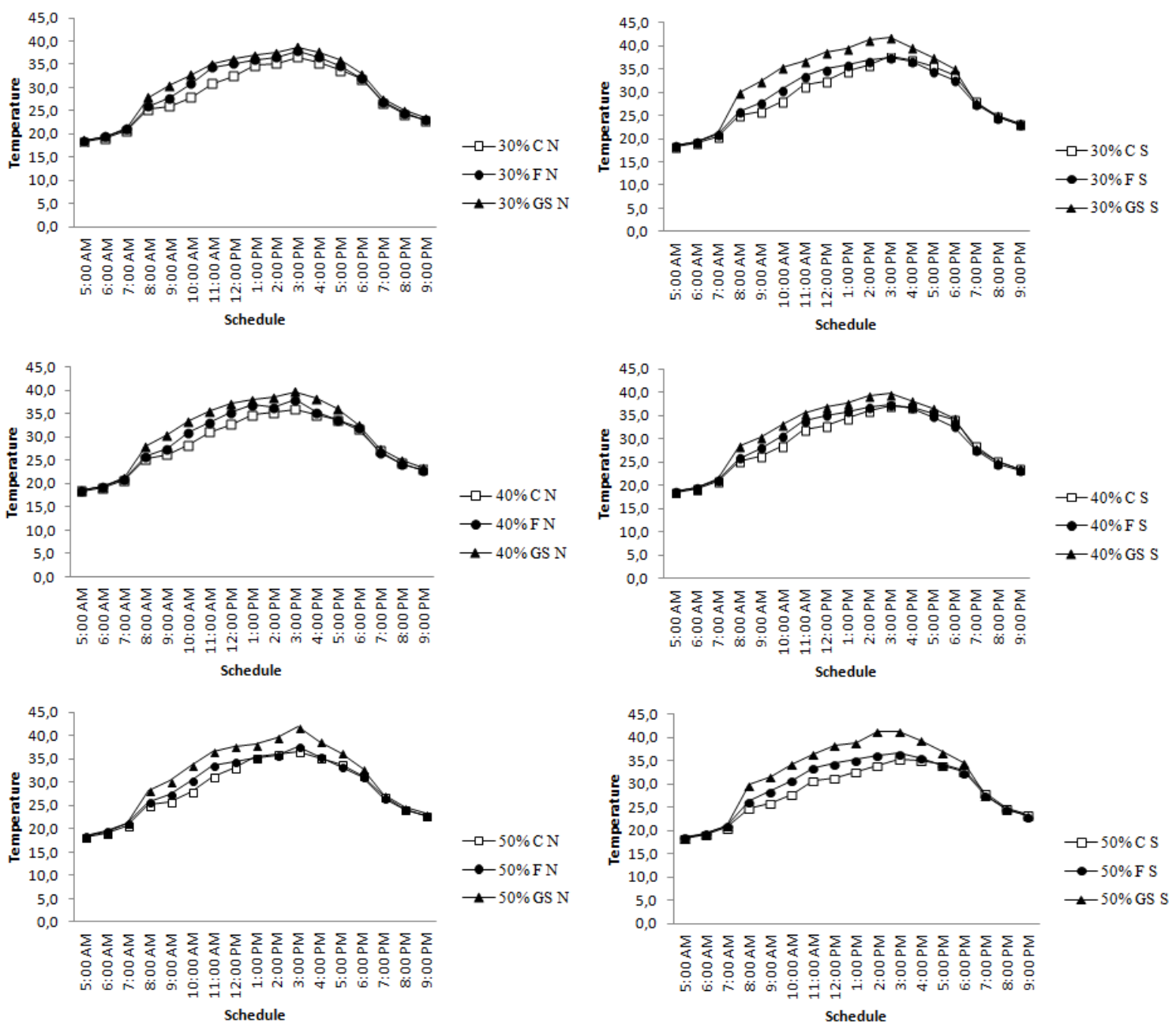

FIGURE 4. Temperature variation in the shed during the critical summer day with the different roofs, with slopes of 30\%, facing North; 30\%, facing South ; 40\%, facing North ; 40\% facing South; 50\%, facing North; and 50\%, facing South.

Figure 5 shows that in the ceramic and fibro roofs, the South-faced slope of $50 \%$ at the temperature peaks demonstrated a difference in relation to the other slopes, and this value was more discrete in the fibro roof, whereas for the galvanized steel there was no difference. Although the estimated radiation was higher in the North-faced roofs, the same behavior was not observed in the South-facing roofs. 

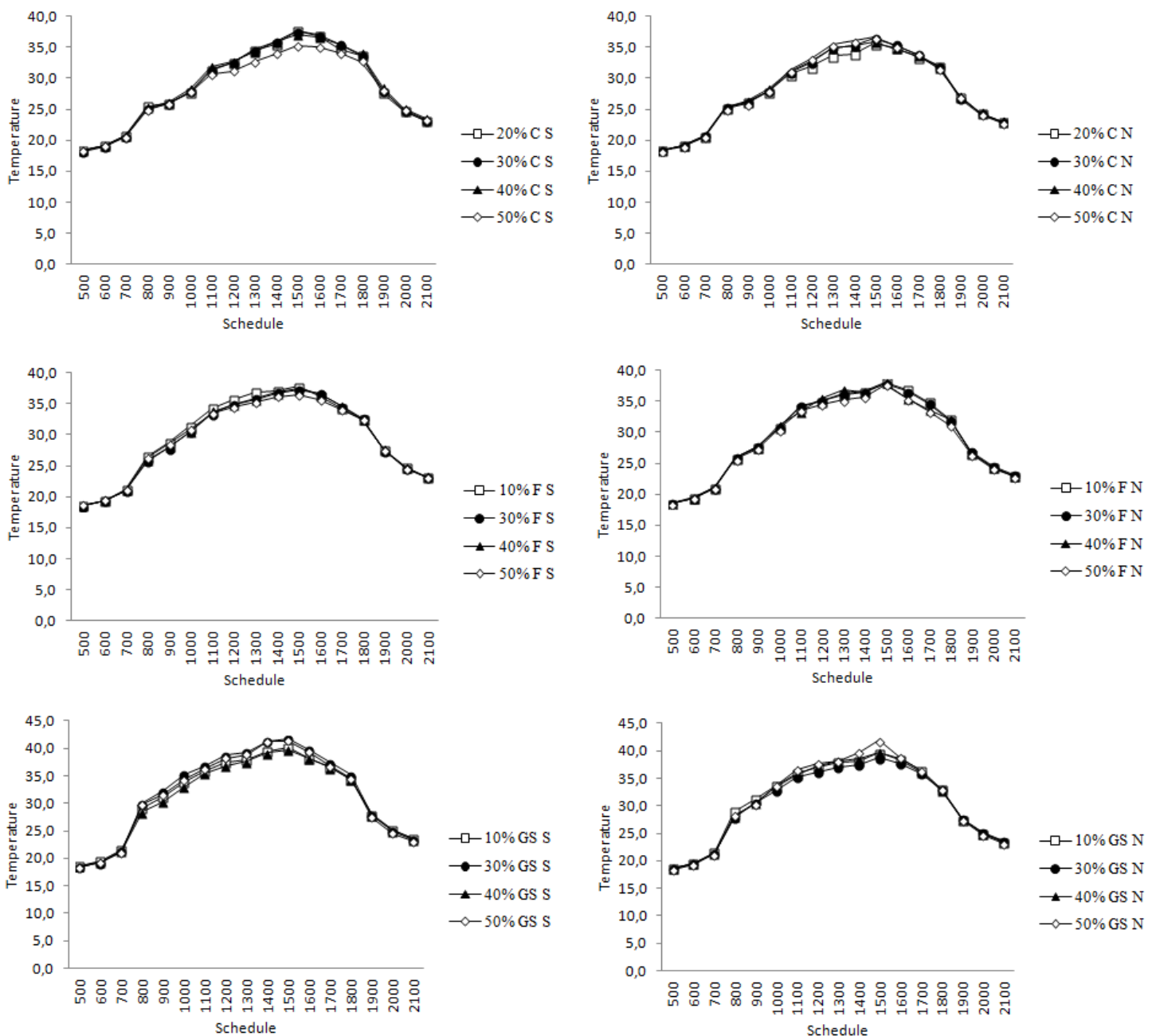

FIGURE 5. Temperature variation in the shed during the critical summer day with the ceramic roof (a - South; b - North) with slopes of 20, 30, 40 and 50\% and in the fibro (c - South; $d$ North) and galvanized-steel roofs (e - South; f - North) with slopes of 10, 30, 40 and $50 \%$.

TABLE 2. Means of the interaction between roofing material and exposure nested with the slope factor on the internal temperature $\left({ }^{\circ} \mathrm{C}\right)$ in the summer and spring.

\begin{tabular}{|c|c|c|c|c|c|c|}
\hline \multicolumn{7}{|c|}{ Summer } \\
\hline & \multicolumn{2}{|c|}{ Ceramic } & \multicolumn{2}{|c|}{ Fibro } & \multicolumn{2}{|c|}{ Galvanized steel } \\
\hline & North & South & North & South & South & North \\
\hline $10 \%$ & - & - & $37.76 \mathrm{aA}$ & $38.42 \mathrm{aA}$ & 38.31aA & 38.32aA \\
\hline $20 \%$ & 37.39aA & $37.87 \mathrm{aA}$ & - & - & - & - \\
\hline $30 \%$ & 37.93aA & $37.85 \mathrm{aA}$ & $37.71 \mathrm{aA}$ & 37.38aB & $38.05 \mathrm{aA}$ & 38.18aA \\
\hline $40 \%$ & $38.30 \mathrm{aA}$ & $37.29 \mathrm{aA}$ & $37.96 \mathrm{aA}$ & $37.32 \mathrm{aB}$ & 38.79aA & 38.57aA \\
\hline $50 \%$ & 38.73abA & $35.64 \mathrm{cA}$ & 37.65abcA & $36.85 b c B$ & $39.87 \mathrm{aA}$ & $39.43 a A$ \\
\hline \multicolumn{7}{|c|}{ Spring } \\
\hline & \multicolumn{2}{|c|}{ Ceramic } & \multicolumn{2}{|c|}{ Fibro } & \multicolumn{2}{|c|}{ Galvanized steel } \\
\hline & North & South & North & South & South & North \\
\hline $10 \%$ & - & - & 36.53aA & 36.91aA & $37.15 \mathrm{aA}$ & 37.06aA \\
\hline $20 \%$ & 35.73aA & $35.68 \mathrm{aA}$ & - & - & - & - \\
\hline $30 \%$ & $36.14 \mathrm{aA}$ & $35.70 \mathrm{aA}$ & $36.44 \mathrm{aA}$ & 36.16aAB & $37.00 \mathrm{aA}$ & 36.89aA \\
\hline $40 \%$ & $36.25 \mathrm{abA}$ & $35.49 \mathrm{bA}$ & 36.84abA & $36.26 \mathrm{abAB}$ & $37.57 \mathrm{aA}$ & 37.39aA \\
\hline $50 \%$ & 36.73bcA & $34.23 \mathrm{dA}$ & 36.38cA & $35.70 \mathrm{cdB}$ & $38.50 \mathrm{aA}$ & $38.25 \mathrm{abA}$ \\
\hline
\end{tabular}


In a computer simulation, YANAGI JR et al. (2001) observed a decrease in the black globe temperature when the roof declivity was increased, although TINOCO (2001) indicates ideal slopes for shed-like constructions should be between 20 and $30^{\circ}$. The only roofing material in which this characteristic of lower internal temperatures was not observed was in galvanized steel.

There was no interaction on the analyzed variables (Table 2) and in relation to the Slopes; there was only significant difference for the fibro roof, both in the summer and spring. When we compare the slopes among the roofs, the South-faced exposure of the ceramic and fibro tile roofs with $50 \%$ showed the best results. Therefore, the total global solar radiation hitting a surface varies according to the exposure and declivity, indicating that one can achieve better thermal performance results in the ceramic and fibro roofs when the slope is increased with greater exposure to the South.

It is interesting to know that one might reach similar thermal performance results in the fibro roof to the ceramic tile when the slope is increased. This is an important fact, given that the fibro tile is cheaper than ceramic tile.

It should be emphasized that the observed temperatures were above the thermal comfort zone for broilers, when average temperatures above $28.0^{\circ} \mathrm{C}$ were recorded inside the models and considering CURTIS (1983), who stated that the thermal comfort zone of poultry is between 18 and $28^{\circ} \mathrm{C}$. Thus, depending on the dimension and duration of the heat stress suffered by birds, undesirable events such as decrease in weight gain or even prostration and death may occur.

Analyzing the thermal performance of the galvanized-steel roof separately, the results are most probably due to the higher conductivity of the metallic materials, i.e., metals have a greater capacity of receiving heat or cold, but are also easier to disperse them, and so they would heat faster than other materials and consequently get cold faster as well. It is possible that the capacity to disperse heat more quickly was not captured at the data collection due to the low air renewal within the model, which probably played a part in the negative result of the galvanized-steel roof. According to OLIVEIRA et al. (2009), surfaces with an elevated reflectance remain colder when exposed to solar radiation, because they absorb less radiation and emit more thermal radiation to the space, and consequently transmit more heat to their surroundings. However, the metallic roof presented the worse thermal performance, even though it had the highest reflectance rate, which may be due to the low emissivity of the material, making its internal environment more uncomfortable.

\section{CONCLUSION}

As the roof slope increased, the internal temperature within the model dropped, so utilizing sharper slopes (50\%) for ceramic and fibro roofs with a larger area facing the South can provide lower temperatures within the animal production facilities.

\section{ACKNOWLEDGEMENTS}

We thank Fundação de Apoio à Pesquisa do Estado de São Paulo - FAPESP for financing this research project.

\section{REFERENCES}

COAN, R.M. Crescimento de grama-esmeralda em diferentes exposições e declividades. 2008. 114 f. Tese (Doutorado). Faculdade de Ciências Agrárias e Veterinárias, Universidade Estadual Paulista, Jaboticabal, 2008.

CURTIS, S.E. Environmental management in animal agriculture. AMES: The Iowa State University, 1983, p. 409. 
FURTADO, D. A.; AZEVEDO de, P. V.; TINOCO, I. F. F.. Análise do conforto térmico em galpões avícolas com diferentes sistemas de acondicionamento. Revista Brasileira de Engenharia Agrícola e Ambiental, Campina Grande, v.7, n.3, p.559-564, 2003.

JACOME, I. M. T. D., FURTADO, D. A., LEAL, A. F., SILVA, J. H. V.; MOURA,J. F. P. Avaliação de índices de conforto térmico de instalações para poedeiras no nordeste do Brasil. Revista Brasileira de Engenharia Agrícola e Ambiental, Campina Grande, v.11, n.5, p. 527-531, 2007.

MURPHY, G.C.E. Similitude in engineering. New York: Ronald Press, 1950.

OLIVEIRA, R. F. M., DONZEL, J. L., ABREU, M. L. T., FERREIRA, R. A., VAZ, R. G. M. V. e CELLA, P. S. Efeitos da temperatura e da umidade relativa sobre o desempenho e o rendimento de cortes nobres de frangos de corte de 1 a 49 dias de idade. Revista Brasileira de Zootecnia, Viçosa, MG, v.35, n.3, p. 797-803, 2006.

PARKER, B.F. Heat transmission caracteristics of sloped roofs exposed to solar radiation. Transactions of the ASAE, St. Joseph, v.8, n.l, p.1-5, 1963.

RODRIGUES, E.H. Desenvolvimento e avaliação de um sistema de resfriamento evaporativo por aspersão intermitente, na cobertura de aviários usando modelos de escala distorcida. 1998. Tese (Doutorado Construções Rurais e Ambiência). Faculdade de Engenharia Agrícola - Universidade Estadual de Campinas, Campinas, 1998.

SANTOS dos P.A., YANAGI JUNIOR, T., TEIXEIRA, V H., Ambiente térmico no interior de modelos de galpões avícolas em escala reduzida com ventilação natural e artificial dos telhados. Engenharia Agrícola, Jaboticabal, v.25, n.3, p.575-584, set./dez. 2005.

SCOLAR, J. Estimativa da irradiação total sobre uma superfície inclinada a partir da irradiação global na horizontal. 2003. 93 f. Tese (Doutorado em Agricultura) - Faculdade de Ciências Agronômicas, Universidade Estadual Paulista, Botucatu, 2003.

SEVEGNANI, K.B.; GHELFI FILHO, H.; DA SILVA, I.J.O. Comparação de vários materiais de cobertura através de índices de conforto térmico. Scientia Agricola, Piracicaba, v. 51, n.1, p. 01-07, jan.,/abr., 1994.

TINÔCO, I. F. F. Avicultura industrial: novos conceitos de materiais, concepções e técnicas construtivas disponíveis para galpões avícolas brasileiros. Revista Brasileira de Ciência Avícola, Campinas, v. 3, n.1, jan./apr. 2001.

TURCO, J. E. P. Modelo de crescimento da planta de soja para terrenos com diferentes exposições e declividades. 1997. 130 f. Tese (Doutorado em Engenharia) - Escola de Engenharia de São Carlos, Universidade de São Paulo, São Carlos, 1997.

YANAGI JUNIOR, T.; DAMASCENO, G.S.; TEIXEIRA, V.H.; XIN, H. Prediction of black globe humidity index in poultry buildings. In: INTERNATIONAL LIVESTOCK ENVIRONMENT SYMPOSIUM, 6., 2001, Louisville. Proceedings... Louisville: ASAE, 2001. p.482-9. 